DOI: $10.2478 / \mathrm{v} \cdot 10169-011-0011-7$

\title{
A GRAPHICAL APPROACH TO YIELD AND BOUNDARY SURFACES OF SELECTED HYPOPLASTIC CONSTITUTIVE EQUATIONS
}

\author{
Z. SIKORA ${ }^{1}$, P. CIEŚLA ${ }^{2}$
}

\begin{abstract}
The article describes how to identify the boundary and yield surface for hypoplastic constitutive equations proposed by $\mathrm{Wu}$, Gudehus and Bauer. It is shown how to identify and plot the surfaces for any equation in this class. Calculation errors are analyzed characteristic for applied set of numerical formulas. In the paper there are computer links to the source code prepared in the MATLAB system, based on instructions in the article. A sample consitutive domains are shown, plotted using the attached computer program.
\end{abstract}

Key words: yield surface, boundary surface, hypoplasticity, constitutive equation, MATLAB, constitutive domain, soil mechanics, finite element method, simulation.

\section{INTRODUCTION}

\subsection{Motivation}

Computational issues in geoengineering are always associated with constitutive laws (usually differential equations of the first order). Their character and validity domain is different for different equations, on the other hand the space in which physical law is defined, should correlate with its experimental scope. Many scientists are trying to create new constitutive equations or improve already existing ones, to reflect the actual behavior of the soil more accurately. They often partly forget that newly created law may correlate with experiments only to a specific point. When the solution moves beyond the field of the correctness, the results of the virtual simulation may lose the physical meaning. There is why a graphical representation of the constitutive law in the stress space at least is a valuable issue, [1].

\footnotetext{
${ }^{1}$ Department of Geotechnics, Geology and Maritime Engineering, Technical University of Gdańsk, e-mail: zbig@pg.gda.pl

${ }^{2}$ Department of Geotechnics, Geology and Maritime Engineering, Technical University of Gdańsk, e-mail: pawel.ciesla@wilis.pg.gda.pl
} 


\subsection{Definitions}

Constitutive equation is a mathematical relationship between the physical stress and strain for any type of material. There is several constitutive equation types belonging to different classes. One of the newest class is called hypoplasticity [2]. Hypoplastic constitutive equations are used to describe nonlinear phenomena, between the load and deformation of soil. They take often into consideration stress rate and stretching, i.e. the basic form of these equations can be written as

$$
\stackrel{\circ}{\mathbf{T}}=\mathbf{H}(\mathbf{T}, \mathbf{D})
$$

where $\mathbf{T}$ is Cauchy stress tensor, $\mathbf{D}$ is stretching tensor, $\stackrel{\circ}{\mathbf{T}}$ stands for Jaumann stress rate, [2], [4].

Definition 1 (Yield surface, [3], [4] ) If for a given stress tensor $\mathbf{T}$ there exists strain rate $\mathbf{D}$ for which

$$
\stackrel{\circ}{\mathbf{T}}=\mathbf{H}(\mathbf{T}, \mathbf{D})=0,
$$

then the stress state $\mathbf{T}$ is to be called the hypoplastic flow in the direction $\mathbf{D}$.

Equation (1.1) can be understood as a sum of a bilinear part $\mathbf{L}$ and nonlinear part $\mathbf{N}$ with respect to $\mathbf{T}$ and $\mathbf{D}$, i.e.

$$
\stackrel{\circ}{\mathbf{T}}=\mathbf{H}\left(\mathbf{T}, \mathbf{D}, C_{1}, \ldots, C_{k}\right)=\mathbf{L}(\mathbf{T}, \mathbf{D})+\mathbf{N}(\mathbf{T})\|\mathbf{D}\| .
$$

$C_{1}, \ldots, C_{k}$ have to be understood as a set of material parameters describing the subjected soil. Applying Euler's theorem for homogeneous function $\mathbf{H}$ in (1.3) and comparing it to (1.2), one obtains equation of the yield surface in the following form

$$
\mathbf{N}^{T} \mathbf{B N}-1=0,
$$

where $\mathbf{B}=\left(\mathbf{A}^{-1}\right)^{T} \mathbf{A}^{-1}$. From Euler's theorem, we know that

$$
\mathbf{A}=\frac{\partial \mathbf{H}}{\partial \mathbf{D}}
$$

since

$$
\stackrel{\circ}{\mathbf{T}}=\frac{\partial \mathbf{H}}{\partial \mathbf{D}}: \mathbf{D}=\frac{\partial \mathbf{L}}{\partial \mathbf{D}}: \breve{\mathbf{D}}+\mathbf{N},
$$

and

$$
\breve{\mathbf{D}}=\frac{\mathbf{D}}{\|\mathbf{D}\|} .
$$

Definition 2 (Boundary surface) Constitutive equation (1.1) clearly defines the boundary surface in the stress space by using the following mathematical dependence, [3], [4]

$$
\left(\mathbf{N}^{T} \mathbf{B T}+\mathbf{T}^{T} \mathbf{B N}\right)^{2}-4 \mathbf{T}^{T} \mathbf{B T}\left(\mathbf{N}^{T} \mathbf{B N}-1\right)=0 .
$$




\subsection{Tools}

The yield surface and the boundary surface can be plotted using a computer program, written in low level language, such as $\mathrm{C} / \mathrm{C}++$. However, the programs in this language require a comprehensive code for linear algebra procedures. On that account usage of a mathematical package, e.g. MATLAB will significantly reduce the size of the code.

Thus, both constitutive surfaces can be plotted using MATLAB 7.10 software. The advantage of the package is better memory management compared to the competing packages such as Mathematica, for instance. All source codes used in this paper are available on the Internet website http://yieldandboundar.sourceforge.net.

\section{AN EXAMPLE WITH SELECTED LAWS}

As a simple example, let us take into consideration the constitutive equation proposed by $\mathrm{Wu},[2]$, [4], i.e.

$$
\stackrel{\circ}{\mathbf{T}}=C_{1} \operatorname{tr}(\mathbf{T}) \mathbf{D}+C_{2} \frac{\operatorname{tr}(\mathbf{T D})}{\operatorname{tr}(\mathbf{T})} \mathbf{T}+C_{3} \frac{\mathbf{T}^{2}}{\operatorname{tr}(\mathbf{T})} \sqrt{\operatorname{tr}\left(\mathbf{D}^{2}\right)}+C_{4} \frac{\left(\mathbf{T}^{*}\right)^{2}}{\operatorname{tr}(\mathbf{T})} \sqrt{\operatorname{tr}\left(\mathbf{D}^{2}\right)},
$$

$$
\mathbf{T}^{*}=\mathbf{T}-\frac{1}{3} \operatorname{tr}(\mathbf{T}) \mathbf{I}
$$

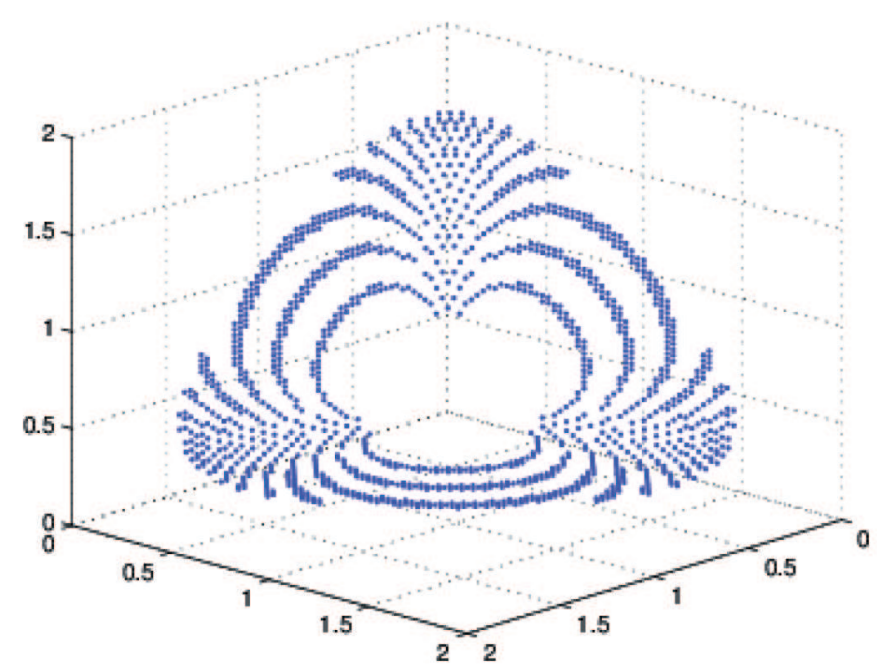

Fig. 1. Yield surface of Wu Wei's constitutive equation plotted using formula (1.4).

Rys. 1. Powierzchnia płynięcia równania konstytutywnego Wu Wei narysowana przy pomocy wzoru (1.4)

Let us try to plot a yield and boundary surface using formulas (1.4) and (1.8). Constants $C_{1}, C_{2}, C_{3}, C_{4}$ depend on type of the soil. For Karlsuhe sand the material 
parameters are as follows $C_{1}=-106.5, C_{2}=-801.5, C_{3}=-797.1, C_{4}=1077.7$. First we have to implement the structure of the both functions (1.4) and (1.8), by creating two files Yield.m and Boundary.m [8]. Both functions have to be used in the main file Main.m [8]. Applying the file Main.m, one obtains a graphical shape of the yield surface and the boundary surface accordingly to Wu Wei's equation (2.1), see Fig. 1.

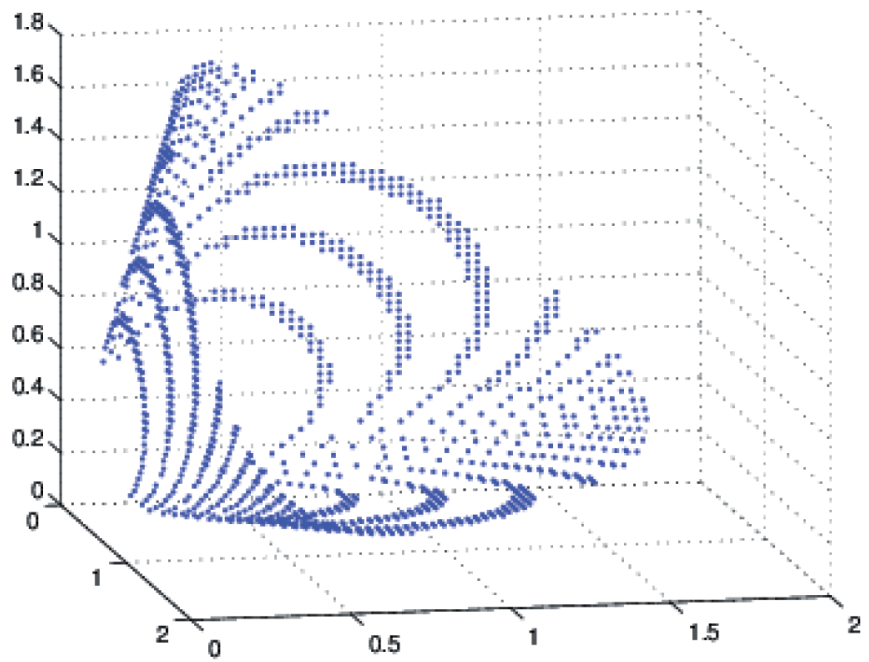

Fig. 2. A rotated view of the yield surface of (2.1) plotted using formula (1.4).

Rys. 2. Obrócony widok powierzchni płynięcia równania (2.1) narysowanej za pomocą (1.4)

The main disadvantage of the presented plot procedure, is the necessity of computing the Frechet derivative (1.5) in general case is to be made manually for each constitutive equation [5].

For automation, one should calculate the derivative of the linear part of the tensor function $\frac{\partial \mathbf{L}}{\partial \mathbf{D}}$ dynamically. The derivative of the linear part of Wu equation (2.1) can be written as

$$
\begin{gathered}
\frac{\partial \mathbf{L}}{\partial \mathbf{D}}=\frac{\partial\left(C_{1} \operatorname{tr}(\mathbf{T}) \mathbf{D}+C_{2} \frac{\operatorname{tr}(\mathbf{T D})}{\operatorname{tr}(\mathbf{T})} \mathbf{T}\right)}{\partial \mathbf{D}}=C_{1} \operatorname{tr}(\mathbf{T}) \frac{\partial \mathbf{D}}{\partial \mathbf{D}}+\frac{C_{2} \mathbf{T}}{\operatorname{tr}(\mathbf{T})} \frac{\partial \operatorname{tr}(\mathbf{T D})}{\partial \mathbf{D}}= \\
=C_{1} \operatorname{tr}(\mathbf{T}) \mathbf{I}+\frac{C_{2} \mathbf{T}}{\operatorname{tr}(\mathbf{T})} \frac{\partial\left(\sum_{i=1}^{3} \sum_{j=1}^{3} T_{i j} D_{j i}\right)}{\partial D_{i j}}= \\
=C_{1} \operatorname{tr}(\mathbf{T}) \mathbf{I}+\frac{C_{2} \mathbf{T}}{\operatorname{tr}(\mathbf{T})} \sum_{i=1}^{3} \sum_{j=1}^{3}\left(\frac{\partial T_{i j}}{\partial D_{i j}} D_{j i}+T_{i j} \frac{\partial D_{i j}}{\partial D_{i j}}\right)=
\end{gathered}
$$




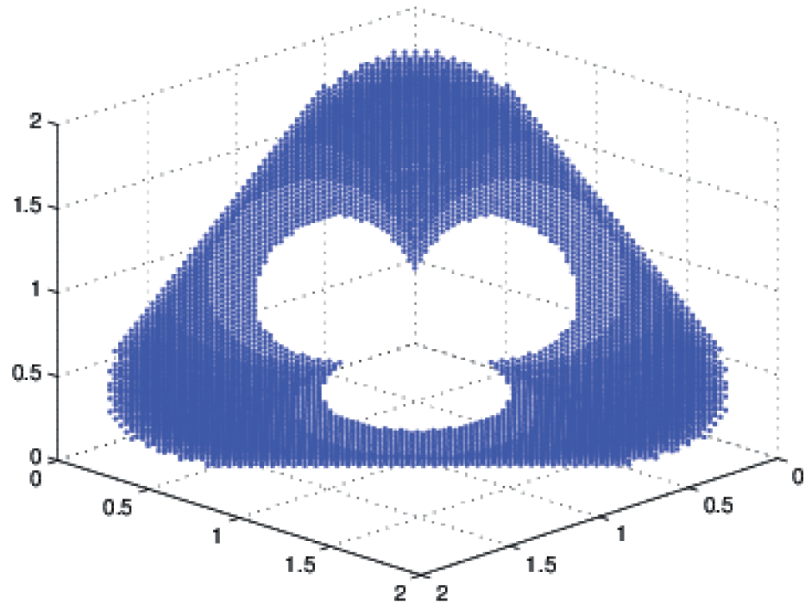

Fig. 3. Boundary surface of (2.1) plotted using formula (1.8).

Rys. 3. Powierzchnia graniczna równania (2.1) narysowana przy pomocy (1.8)

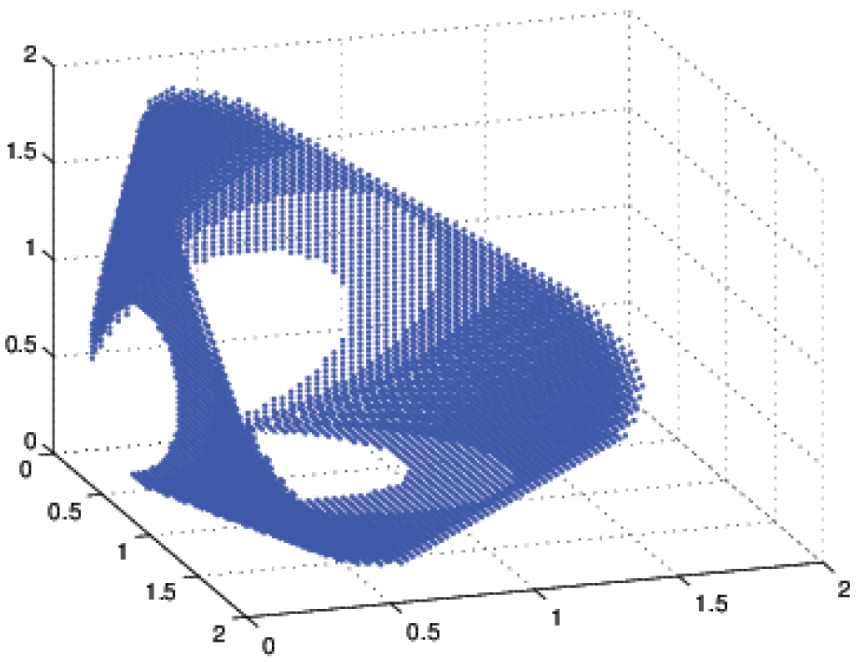

Fig. 4. A rotated view of the boundary surface of (2.1) plotted using formula (1.8). Rys. 4. Obrócony widok powierzchni granicznej równania (2.1) narysowanej przy pomocy (1.8) 


$$
=C_{1} \operatorname{tr}(\mathbf{T}) \mathbf{I}+\frac{C_{2} \mathbf{T}}{\operatorname{tr}(\mathbf{T})} T_{i j} \frac{\partial\left(\sum_{i=1}^{3} \sum_{j=1}^{3} D_{i j}\right)}{\partial D_{i j}}=C_{1} \operatorname{tr}(\mathbf{T}) \mathbf{I}+\frac{C_{2} \mathbf{T}^{2}}{\operatorname{tr}(\mathbf{T})} .
$$

Substituting $\mathbf{T}=\left[\begin{array}{lll}T_{11} & T_{12} & T_{13} \\ T_{21} & T_{22} & T_{23} \\ T_{31} & T_{32} & T_{33}\end{array}\right]$ and $\mathbf{D}=\left[\begin{array}{lll}D_{11} & D_{12} & D_{13} \\ D_{21} & D_{22} & D_{23} \\ D_{31} & D_{32} & D_{33}\end{array}\right]$ to (2.3) we obtain a trivial transformation yielding

$$
\frac{\partial \mathbf{L}}{\partial \mathbf{D}}=C_{1}\left(T_{11}+T_{22}+T_{33}\right) \mathbf{I}+\frac{C_{2}}{T_{11}+T_{22}+T_{33}}\left[\begin{array}{lll}
T_{11} T_{11} & T_{12} T_{12} & T_{13} T_{13} \\
T_{21} T_{21} & T_{22} T_{22} & T_{23} T_{23} \\
T_{31} T_{31} & T_{32} T_{32} & T_{33} T_{33}
\end{array}\right]
$$

Derivatives (2.3) can be replaced by their numerical approximations, i.e.

$$
\begin{aligned}
& \lim _{h \rightarrow 0} \frac{\left(T_{11}+T_{22}+T_{33}\right)\left(D_{11}+h\right)-\left(T_{11}+T_{22}+T_{33}\right) D_{11}}{h} \approx \\
& \approx \frac{\left(T_{11}+T_{22}+T_{33}\right)\left(D_{11}+h\right)-\left(T_{11}+T_{22}+T_{33}\right)\left(D_{11}-h\right)}{2 h}
\end{aligned}
$$

and

$$
\begin{aligned}
& \lim _{h \rightarrow 0} \frac{\left(\frac{T_{11}\left(D_{11}+h\right)+T_{12} D_{21}+T_{13} D_{31}}{T_{11}+T_{22}+T_{33}}-\frac{T_{11} D_{11}+T_{12} D_{21}+T_{13} D_{31}}{T_{11}+T_{22}+T_{33}}\right) T_{11}}{h} \approx \\
& \approx \frac{\left(\frac{T_{11}\left(D_{11}+h\right)+T_{12} D_{21}+T_{13} D_{31}}{T_{11}+T_{22}+T_{33}}-\frac{T_{11}\left(D_{11}-h\right)+T_{12} D_{21}+T_{13} D_{31}}{T_{11}+T_{22}+T_{33}}\right) T_{11}}{2 h} .
\end{aligned}
$$

Definition 3 Let denote the numerical approximation of a derivative $\frac{\partial \mathbf{L}}{\partial \mathbf{D}}$, as $\left(\frac{\partial \mathbf{L}}{\partial \mathbf{D}}\right)_{\text {num }}$ and the theoretical one as $\left(\frac{\partial \mathbf{L}}{\partial \mathbf{D}}\right)_{\text {theor }}$. The absolute error of the numerical derivative $\left(\frac{\partial \mathbf{L}}{\partial \mathbf{D}}\right)_{\text {num }}$ is defined therefore, [6]

$$
\left\|\left(\frac{\partial \mathbf{L}}{\partial \mathbf{D}}\right)_{\text {num }}-\left(\frac{\partial \mathbf{L}}{\partial \mathbf{D}}\right)_{\text {theor }}\right\|
$$


The relative error of the numerical derivative of $\left(\frac{\partial \mathbf{L}}{\partial \mathbf{D}}\right)_{\text {num }}$ is

$$
\left\|\frac{\left(\frac{\partial \mathbf{L}}{\partial \mathbf{D}}\right)_{\text {num }}-\left(\frac{\partial \mathbf{L}}{\partial \mathbf{D}}\right)_{\text {theor }}}{\left(\frac{\partial \mathbf{L}}{\partial \mathbf{D}}\right)_{\text {num }}}\right\| \text {. }
$$

For any function $f$ with the proper attribute of differentiation, truncation error [6] of the two-point numerical derivative at point $x$ can be estimated by $O\left(h^{2}\right)$ because

$$
\begin{gathered}
f(x+h)=f(x)+h f^{\prime}(x)+\frac{h^{2}}{2} f^{\prime \prime}(x)+\frac{h^{3}}{6} f^{\prime \prime \prime}\left(\xi_{1}\right), \\
f(x-h)=f(x)-h f^{\prime}(x)+\frac{h^{2}}{2} f^{\prime \prime}(x)-\frac{h^{3}}{6} f^{\prime \prime \prime}\left(\xi_{2}\right), \\
f^{\prime}(x)=\frac{f(x+h)-f(x-h)}{2 h}+\frac{h^{2}}{12}\left(f^{\prime \prime \prime}\left(\xi_{1}\right)+f^{\prime \prime \prime}\left(\xi_{2}\right)\right),
\end{gathered}
$$

where $\xi_{1} \in(x, x+h), \xi_{2} \in(x-h, x)$. There is also essential the rounding error $r f(x)$, associated with the finite precision variables stored by the computer. The value of $r$ depends on the precision of variables used in the computer program. Taking into consideration above, i.e. the truncation error and rounding one, we get a new approximation

$$
f^{\prime}(x)=\frac{f(x+h)-f(x-h)}{2 h}+\frac{r f(x)}{h}+O\left(h^{2}\right)
$$

The factor $\frac{r}{h}$ generates the increasing of the error while the value of $h$ decreases. Derivative of the numerical error can be estimated as

$$
E r \approx \frac{r}{h}+h^{2}
$$

The error reaches a minimum for $h=r^{1 / 3}$.

Using MATLAB system, one can compute all the components of the matrix $\frac{\partial \mathbf{L}}{\partial \mathbf{D}}$. As an example, let analyze again the constitutive equation proposed by $\mathrm{Wu}$ [2], [4]. Thereafter, some procedures dealing the issues are included, [8]. First, one needs to implement linear and nonlinear part of (2.1) in files Linear.m and Nonlinear.m, [8]. The procedures in AutoYield.m and AutoBoundary.m apply previously implemented functions.

Hereafter next example of hypoplastic constitutive equation proposed by GudehusBauer [3], [4], [7]. This constitutive law is quite known as an effective physical decription of soil deformation with parameters, which have a proper mechanical meaning. To 
Errors (2.4) for different $h$ on interval [3,6]. Błędy (2.4) dla różnych $h$ na przedziale [3,6]

\begin{tabular}{|l|c|}
\hline $\mathrm{h}$ & Range of error \\
\hline 0.1 & {$\left[10^{-13}, 10^{-12}\right]$} \\
\hline 0.01 & {$\left[10^{-13}, 10^{-11}\right]$} \\
\hline 0.001 & {$\left[10^{-12}, 10^{-10}\right]$} \\
\hline 0.0001 & {$\left[10^{-11}, 10^{-9}\right]$} \\
\hline
\end{tabular}

describe the initial state, one uses two state parameters: $\left(e, \mathbf{T}_{s}\right)$, [3], [4], i.e. $e$ - void ratio, $\mathbf{T}_{s}$ - Cauchy stress tensor.

Index $s$ indicates the value related to the skeleton of the granular material. The constitutive function has the form

$$
\stackrel{\circ}{\mathbf{T}}=f_{b} f_{e}\left[\overline{\mathbf{L}}\left(\hat{\mathbf{T}}_{s}, \mathbf{D}_{s}\right)+f_{d} \hat{\mathbf{N}}\left(\hat{\mathbf{T}}_{s}\right)\left\|\mathbf{D}_{s}\right\|\right]
$$

where

$$
\hat{\mathbf{T}}_{s}=\frac{\mathbf{T}_{s}}{\operatorname{tr}\left(\mathbf{T}_{s}\right)} .
$$

Its linear and nonlinear parts are as follows

$$
\overline{\mathbf{L}}=\frac{1}{a_{1}^{2}} \mathbf{D}_{s}+\hat{\mathbf{T}}_{s} \operatorname{tr}\left(\hat{\mathbf{T}}_{s} \mathbf{D}_{s}\right),
$$

$$
\overline{\mathbf{N}}=\frac{1}{a_{1}}\left(\hat{\mathbf{T}}_{s}+\hat{\mathbf{T}}_{s}^{*}\right),
$$

where

$$
\begin{aligned}
\hat{\mathbf{T}}_{s}^{*}=\hat{\mathbf{T}}_{s}-\frac{1}{3} \mathbf{I}, \quad a_{1} & =c_{1}+c_{2}[1+\cos (3 \theta)]\left\|\hat{\mathbf{T}}_{s}^{*}\right\|, \quad \cos (3 \theta)=\frac{-\sqrt{6} \operatorname{tr}\left(\hat{\mathbf{T}}_{s}^{* 3}\right)}{\left[\operatorname{tr}\left(\hat{\mathbf{T}}_{s}^{* 2}\right)\right]^{\frac{3}{2}}}, \\
c_{1} & =\sqrt{\frac{3}{8}} \frac{3-\sin \phi_{c}}{\sin \phi_{c}}, \quad c_{2}=\frac{3}{8} \frac{3+\sin \phi_{c}}{\sin \phi_{c}} .
\end{aligned}
$$

Functions $\overline{\mathbf{L}}$ and $\overline{\mathbf{N}}$ for Gudehus-Bauer constitutive law within MATLAB environment are inplemented in GudehusBauerLinear.m and GudehusBauerNonlinear.m, [8]. The function GudehusBauerLinear in AutoYield procedure and the function GudehusBauerNonlinear in AutoBoundary procedure can be implemented as written in the procedures AutoYieldGudehusBauer.m and AutoBoundaryGudehusBauer.m, [8].

The final stage of programming is to create a graphical user interface in MyGUI.m, which uses above created functions [8]. Compilation of the file MyGUI.m, generates 


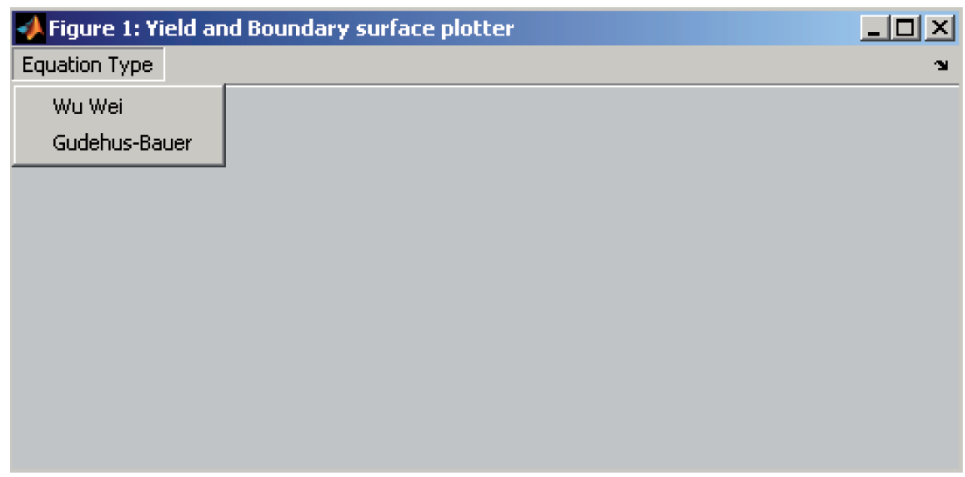

Fig. 5. Main window of the graphical user interface. Rys. 5. Główne okno graficznego interfejsu użytkownika

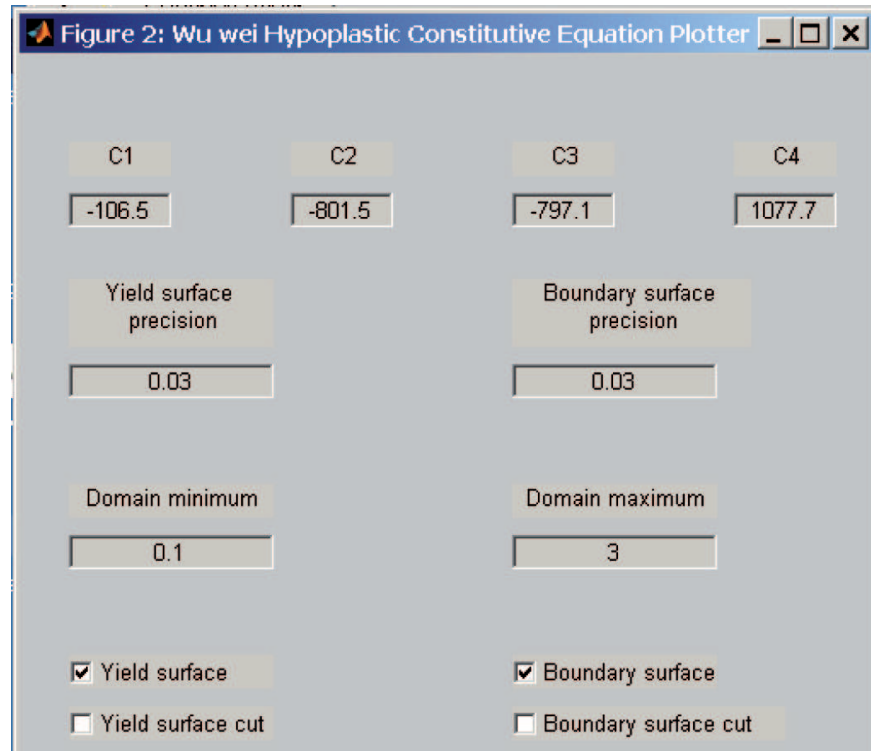

Bound Calculation progress: $91.2673 \%$

Plot surfaces

Fig. 6. Wu Hypoplastic Constitutive Equation Plotter. Rys. 6. Okno Wu Hypoplastic Constitutive Equation Plotter 


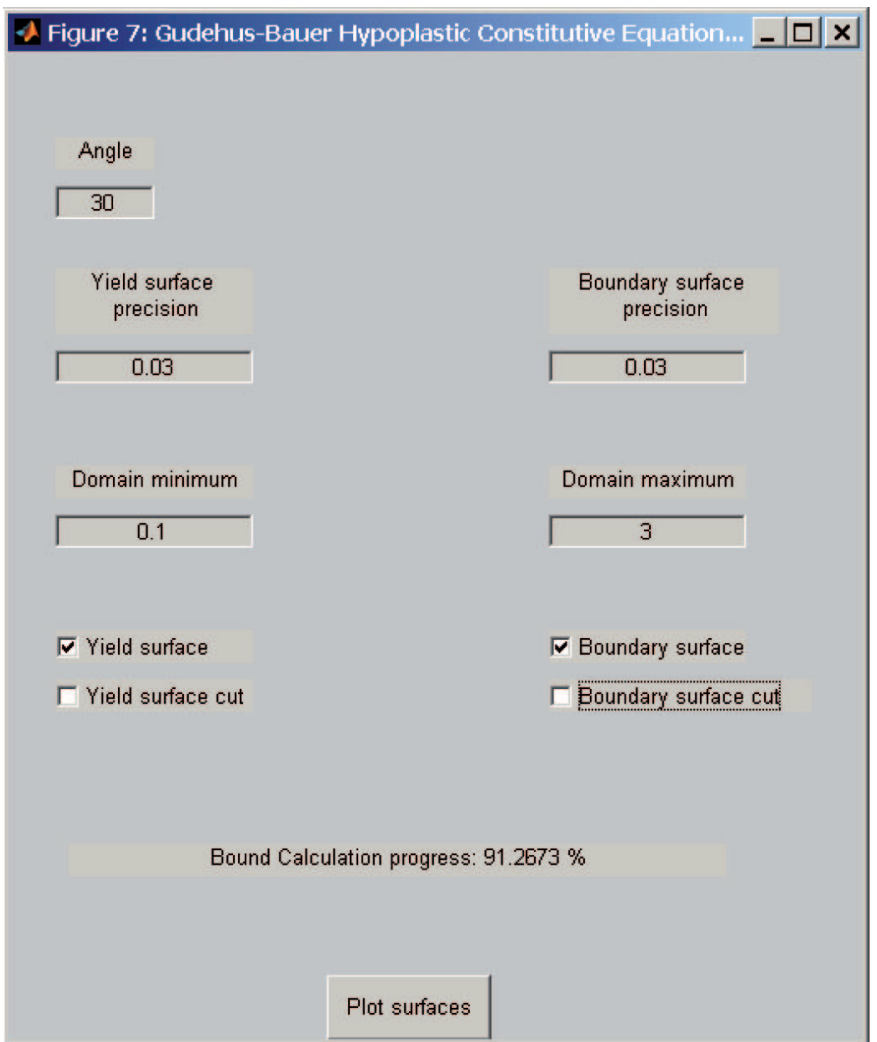

Fig. 7. Gudehus-Bauer Hypoplastic Constitutive Equation Plotter. Rys. 7. Okno Gudehus-Bauer Hypoplastic Constitutive Equation Plotter

interface with the parent window, Fig. 5, and the children windows Fig. 6 and Fig. 7 appropriately.

There is possible two automated modules Wu Wei Hypoplastic Constitutive Equation Plotter and Gudehus-Bauer Hypoplastic Constitutive Equation Plotter, which constitute four new drawings (8) - (11). In both modules, one can determine the area of domain analysis defining Domain minimum and Domain maximum in (6) and (7). Controls Yield surface precision and Boundary surface precision allow to determine the accuracy of the analysis. The calculation can be reduced to only one type of surface, using check-boxes Yield surface and Boundary surface. One can use check-box Yield surface cut or Boundary surface cut to reduce the computation time by drawing only the surfaces' cuts. Controls C1, C2, C3, C4 from the module Wu Wei Hypoplastic Constitutive Equation Plotter allow to define the material parameters of a soil. Angle control from the Gudehus-Bauer Hypoplastic Constitutive Equation Plotter module allows to specify the critical angle of internal friction. 


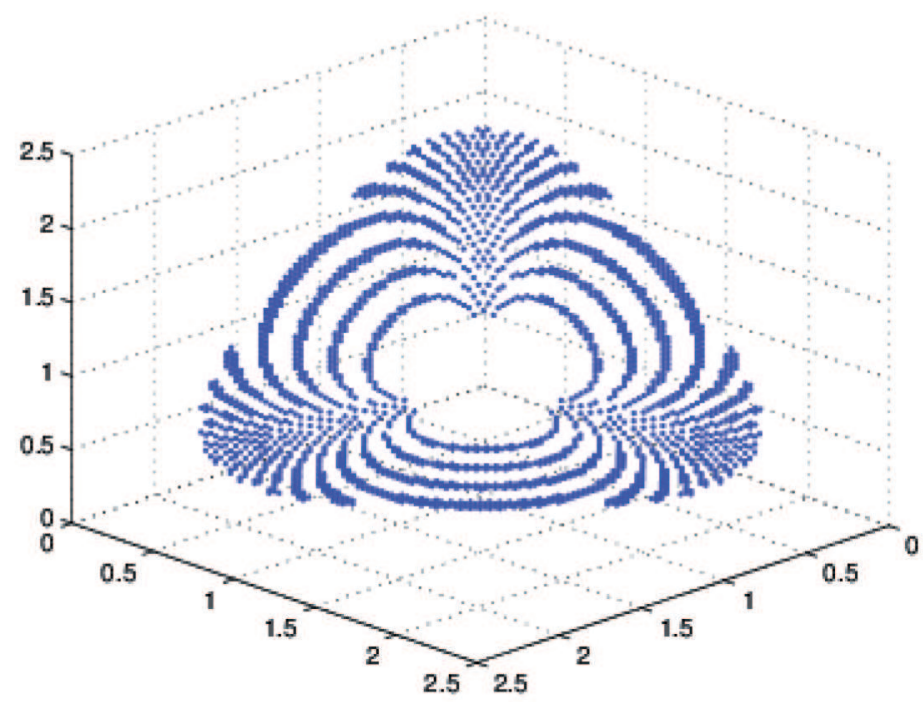

Fig. 8. Yield surface of (2.1) plotted using Yield and Boundary plotter application. Rys. 8. Powierzchnia płynięcia (2.1) narysowana za pomocą Yield and Boundary plotter

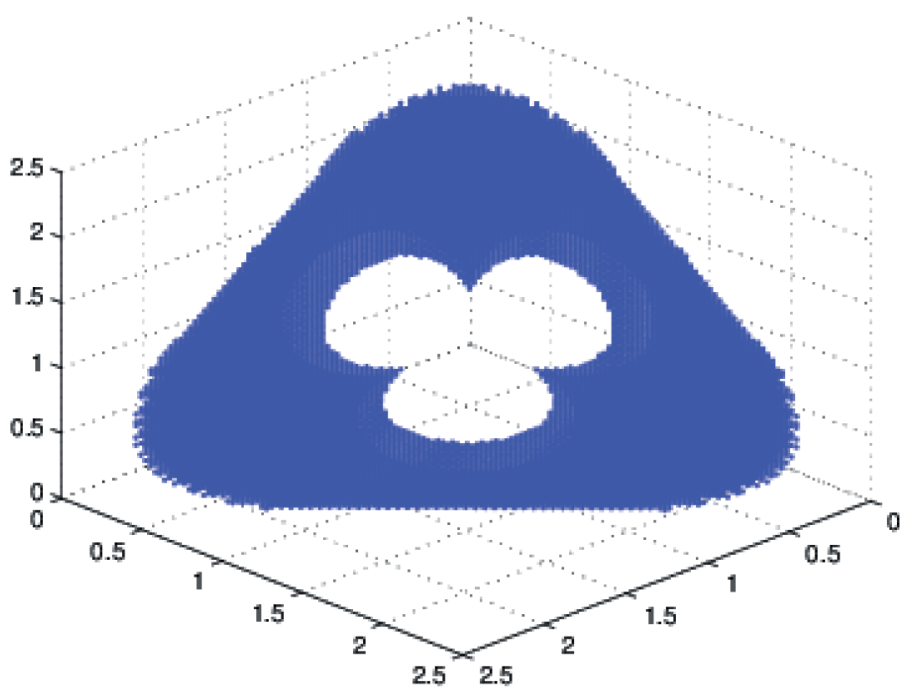

Fig. 9. Boundary surface of (2.1) plotted using Yield and Boundary plotter application. Rys. 9. Powierzchnia graniczna (2.1) narysowana za pomocą Yield and Boundary plotter 


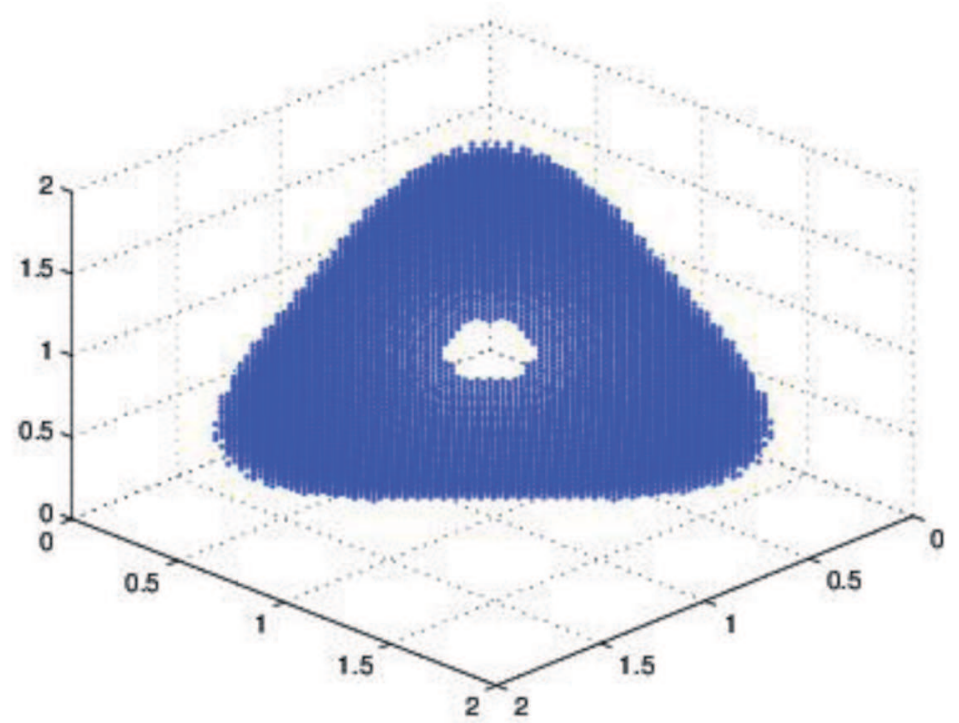

Fig. 10. Yield surface of (2.8) plotted using Yield and Boundary plotter application. Rys. 10. Powierzchnia płynięcia (2.8) narysowana za pomocą Yield and Boundary plotter

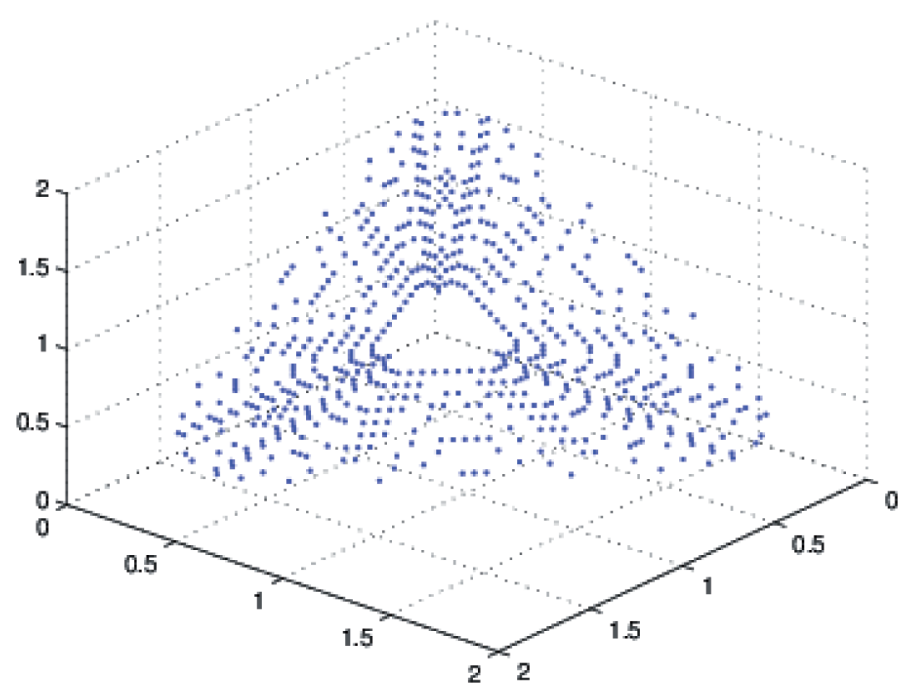

Fig. 11. Boundary surface of (2.8) plotted using Yield and Boundary plotter application. Rys. 11. Powierzchnia graniczna (2.8) narysowana za pomocą Yield and Boundary plotter 


\section{Conclusions}

Checking the yield surface and the boundary surface is extremely important in the process of creating any constitutive laws. Virtual simulation of soil behaviors using the newly created constitutive equations, can give auxiliary visual effects of the constitutive domain which finally can be compared with experimental data-knowledge. The correctness of visualization can be narrowed down by the mathematical negligence of the subject law. The shapes of the domain of generally known constitutive functions used for virtual simulation of the soil are similar. The presented computer program after simple modification allows to create an image of any constitutive equation and check its mathematical correctness.

\section{REFERENCES}

1. Z. Sikora, Control conditions for geocomputing within general hypoplasticity, Proceedings of International Conference on modern building materials, structures and techniques, Vilnius Gediminas Technical University, pp. 1161-1167, 2010.

2. D. Kolymbas, Introduction to Hypoplasticity, A.A. Balkema 2000.

3. Z. SiкоRA, Hypoplastic flow of granular materials. A numerical approach, University of Karlsuhe, Technical University of Gdansk 1991.

4. Z. Sikora, Sondowanie statyczne, Wydawnictwa Naukowo-Techniczne 2006.

5. W. Wu, E. Bauer, D. Kolymbas, Hypoplastic constitutive model with critical state for granular materials, Mechanics of Materials 23, 45-69, 1996.

6. D. Kincaid, W. Cheney, Numerical analysis. Mathematics of scientific computing, Brooks/Cole Publishing Company 1990

7. E. Bauer, W. Wu, W. Huang, Modelling inherent and induced anisotropy in Hypoplasicity, QuaDPM'03 Workshop on Quasi-static Deformations of Particulate Materials.

8. http://yieldandboundar.sourceforge.net

\section{Streszczenie}

W artykule przedstawiono sposób wyznaczania powierzchni płynięcia oraz powierzchni granicznej dla przykładowych równań konstytutywnych w ramach teorii hypoplastyczności zaproponowanych przez Wu, Gudehus'a oraz Bauer'a. Pokazano jak wyznaczać i wykreślać obie powierzchnie dynamicznie dla dowolnych równań tej klasy. Przeanalizowano błędy obliczeniowe charakterystyczne dla użytych formuł numerycznych. W pracy podano linki do komputerowych kodów źródłowych przygotowanych w komercyjnym systemie MATLAB, stosujących instrukcje przedstawione w niniejszym artykule. Przedstawiono przykładowe dziedziny równań konstytutywnych narysowanych przy pomocy załączonego programu komputerowego.

Remarks on the paper should be sent to the Editorial Office no later than September 30, 2011
Received December 15, 2010 revised version May 15, 2011 